\title{
Guidelines for authors
}

Authors are obliged to follow the instructions:

1. The text should be written in WORD (97- ) format with either *.doc or *.rtf extension, with the preferred length of 40000 characters. All the special fonts eg. Greek or Hebrew, should be sent by the authors.

2. Font: Times New Roman 12 points.

3. Line spacing: 1,5 .

4. Each article should include: abstract (in English and in the language of the paper, if it is written in a different laguage), keywords (in Polish and English), introduction, chapters and/or subsections, conclusion, bibliography:

- abstract should consist of 200-250 words (about 600 characters) and summarize the main points of the article;

- key words should not consist of the words used in the title of the article (min 3 max 6 words);

- references at the end of the article, alphabetically, including surnames.

5. Information of the funding sources (at the beginning of the article, in the first footnote).

6. Neither bold nor underline should be used to highlight the words; ex p a n d e d only.

7. Block quotation (5 lines or more) - font: 11 points, line spacing: 1, paragraph indent on the left.

8. Footnotes:

a) text notes and bibliographical notes - Times New Roman 10 points with superscript reference

b) Latin abbreviations: ibidem, idem, eadem, op. cit., passim;

c) footnotes - examples: 


\section{Literature:}

\section{Book}

One author

Pollan, Michael. 2006. The Omnivore's Dilemma: A Natural History of Four Meals. New York: Penguin.

(Pollan 2006, 99-100)

Two or more authors

Ward, Geoffrey C., and Ken Burns. 2007. The War: An Intimate History, 1941-1945. New York: Knopf.

(Ward and Burns 2007, 52)

For four or more authors, list all of the authors in the reference list; in the text, list only the first author, followed by et al. ("and others"):

(Barnes et al. 2010)

Editor, translator, or compiler instead of author

Lattimore, Richmond, trans. 1951. The Iliad of Homer. Chicago: University of Chicago Press.

(Lattimore 1951, 91-92)

Editor, translator, or compiler in addition to author

García Márquez, Gabriel. 1988. Love in the Time of Cholera. Translated by Edith Grossman. London: Cape.

(García Márquez 1988, 242-55)

Chapter or other part of a book

Kelly, John D. 2010. “Seeing Red: Mao Fetishism, Pax Americana, and the Moral Economy of War.” In Anthropology and Global Counterinsurgency, edited by John D. Kelly, Beatrice Jauregui, Sean T. Mitchell, and Jeremy Walton, 67-83. Chicago: University of Chicago Press.

(Kelly 2010, 77)

Chapter of an edited volume originally published elsewhere (as in primary sources) Cicero, Quintus Tullius. 1986. "Handbook on Canvassing for the Consulship.” In Rome: Late Republic and Principate, edited by Walter Emil Kaegi Jr. and Peter White. Vol. 2 of University of Chicago Readings in Western Civilization, edited by John 
Boyer and Julius Kirshner, 33-46. Chicago: University of Chicago Press. Originally published in Evelyn S. Shuckburgh, trans., The Letters of Cicero, vol. 1 (London: George Bell \& Sons, 1908).

(Cicero 1986, 35)

Preface, foreword, introduction, or similar part of a book

Rieger, James. 1982. Introduction to Frankenstein; or, The Modern Prometheus, by Mary Wollstonecraft Shelley, xi-xxxvii. Chicago: University of Chicago Press.

(Rieger 1982, xx-xxi)

\section{Book published electronically}

If a book is available in more than one format, cite the version you consulted. For books consulted online, list a URL; include an access date only if one is required by your publisher or discipline. If no fixed page numbers are available, you can include a section title or a chapter or other number.

Austen, Jane. 2007. Pride and Prejudice. New York: Penguin Classics. Kindle edition. Kurland, Philip B., and Ralph Lerner, eds. 1987. The Founders' Constitution. Chicago: University of Chicago Press. http://press-pubs.uchicago.edu/founders/.

(Austen 2007)

(Kurland and Lerner, chap. 10, doc. 19)

\section{Journal article}

\section{Article in a print journal}

In the text, list the specific page numbers consulted, if any. In the reference list entry, list the page range for the whole article.

Weinstein, Joshua I. 2009. “The Market in Plato’s Republic.” Classical Philology 104:439-58.

(Weinstein 2009, 440)

\section{Article in an online journal}

Include a DOI (Digital Object Identifier) if the journal lists one. A DOI is a permanent ID that, when appended to http://dx.doi.org/ in the address bar of an Internet browser, will lead to the source. If no DOI is available, list a URL. Include an access date only if one is required by your publisher or discipline. 
Kossinets, Gueorgi, and Duncan J. Watts. 2009. “Origins of Homophily in an Evolving Social Network.” American Journal of Sociology 115:405-50. Accessed February 28, 2010. doi:10.1086/599247.

(Kossinets and Watts 2009, 411)

\section{Article in a newspaper or popular magazine}

Newspaper and magazine articles may be cited in running text ("As Sheryl Stolberg and Robert Pear noted in a New York Times article on February 27, 2010,...”), and they are commonly omitted from a reference list. The following examples show the more formal versions of the citations. If you consulted the article online, include a URL; include an access date only if your publisher or discipline requires one. If no author is identified, begin the citation with the article title.

Mendelsohn, Daniel. 2010. “But Enough about Me.” New Yorker, January 25.

Stolberg, Sheryl Gay, and Robert Pear. 2010. "Wary Centrists Posing Challenge in Health Care Vote.” New York Times, February 27. Accessed February 28, 2010. http:// www.nytimes.com/2010/02/28/us/politics/28health.html.

(Mendelsohn 2010, 68)

(Stolberg and Pear 2010)

\section{Book review}

Kamp, David. 2006. “Deconstructing Dinner.” Review of The Omnivore's Dilemma: A Natural History of Four Meals, by Michael Pollan. New York Times, April 23, Sunday Book Review. http://www.nytimes.com/2006/04/23/books/review/23kamp.html. (Kamp 2006)

\section{Thesis or dissertation}

Choi, Mihwa. 2008. “Contesting Imaginaires in Death Rituals during the Northern Song Dynasty.” PhD diss., University of Chicago.

(Choi 2008)

\section{Paper presented at a meeting or conference}

Adelman, Rachel. 2009. “' 'Such Stuff as Dreams Are Made On’: God's Footstool in the Aramaic Targumim and Midrashic Tradition.” Paper presented at the annual 
meeting for the Society of Biblical Literature, New Orleans, Louisiana, November 21-24.

(Adelman 2009)

\section{Website}

A citation to website content can often be limited to a mention in the text ("As of July 19, 2008, the McDonald's Corporation listed on its website ...”). If a more formal citation is desired, it may be styled as in the examples below. Because such content is subject to change, include an access date or, if available, a date that the site was last modified. In the absence of a date of publication, use the access date or last-modified date as the basis of the citation.

Google. 2009. “Google Privacy Policy.” Last modified March 11. http://www.google. com/intl/en/privacypolicy.html.

McDonald's Corporation. 2008. “McDonald's Happy Meal Toy Safety Facts.” Accessed July 19. http://www.mcdonalds.com/corp/about/factsheets.html.

(Google 2009)

(McDonald's 2008)

\section{Blog entry or comment}

Blog entries or comments may be cited in running text ("In a comment posted to The Becker-Posner Blog on February 23, 2010,...”), and they are commonly omitted from a reference list. If a reference list entry is needed, cite the blog post there but mention comments in the text only. (If an access date is required, add it before the URL; see examples elsewhere in this guide.)

Posner, Richard. 2010. “Double Exports in Five Years?” The Becker-Posner Blog, February 21. http://uchicagolaw.typepad.com/beckerposner/2010/02/double-exports-in-five-years-posner.html.

(Posner 2010)

\section{E-mail or text message}

E-mail and text messages may be cited in running text ("In a text message to the author on March 1, 2010, John Doe revealed ...”), and they are rarely listed in a reference list. In parenthetical citations, the term personal communication (or pers. comm.) can be used. 
(John Doe, e-mail message to author, February 28, 2010)

or

(John Doe, pers. comm.)

\section{Item in a commercial database}

For items retrieved from a commercial database, add the name of the database and an accession number following the facts of publication. In this example, the dissertation cited above is shown as it would be cited if it were retrieved from ProQuest's database for dissertations and theses.

Choi, Mihwa. 2008. "Contesting Imaginaires in Death Rituals during the Northern Song Dynasty.” PhD diss., University of Chicago. ProQuest (AAT 3300426).

Other guidelines can be found on:

http://www.chicagomanualofstyle.org/tools_citationguide.html

9. Neither word breaker nor additional text formatting is required.

10. Pictures and photographs should be attached as separate files and saved in .tif .jpg or .cdr format of the highest possible resolution (min. $300 \mathrm{dpi}$ ). They should be numbered according to their order of appearance in the text, relevant references to the pictures and figures should be made in the text.

11. Charts in Corel Draw or Microsoft Excel.

12. All tables, charts and pictures should consist of the number, title, source or reference.

13. Tables, charts or pictures from the Internet cannot be used.

14. If the manuscript contains material (data, information, tables, charts or pictures) that is the intellectual property and copyright of any person(s) other than the Author(s), then permission of the copyright owner(s) to publish that material is required.

15. Note about Author should include degree, affiliation, publications, field of interest and e-mail address.

16. Authors Declaration Form should be signed and either sent or scanned with the manuscript.

17. When the manuscript is approved by the Editorial, authors should print, sign and sent back the publishing contract http://www.wydawnictwoumk.pl/zasoby/_File/pdfy/Umowa_z_autorem_artykulu_-_czasopismo_2013.pdf 